\title{
The Effect of Sales Tax Rates on Food
}

\section{Exemptions}

\author{
Claudio A. Agostini*
}

November 2004

\begin{abstract}
In this paper I explore the relationship between the sales tax rate and the tax treatment of food in American states. One of the main difficulties in the empirical estimation of this relationship is that state governments set the two tax policy variables. This produces a potential endogeneity problem that would bias the estimates if not considered. I use instrumental variables to solve the problem and to identify the effect of the sales tax rate on the probability of having a food exemption. The empirical results show that, on average, a one percentual point increase in the sales tax rate increases by $20 \%$ the probability of having a food exemption.

JEL: H71, H73

Keywords: Food Exemption, Sales Tax, Instrumental Variables
\end{abstract}

\section{Introduction}

The optimal tax literature, in general, does not predict a food exemption as an optimal solution when implementing a sales tax. Ramsey optimal tax

\footnotetext{
*Department of Economics, Universidad Alberto Hurtado, Santiago, Chile. Email: agostini@uahurtado.cl
} 
rules, for example, suggests that food should be taxed more heavily because its demand is probably more inelastic.

If distributional considerations and individual endowments are introduced to Ramsey model, then the compensated reduction in demand with the optimal tax structure is smaller: (1) the more the good is consumed by individuals with a high net social marginal utility of income; (2) the more the good is consumed by households with a high marginal propensity to consume taxed goods. A commodity with a low elasticity of demand should have a high tax on efficiency grounds, but since the consumption of such a commodity rises only slowly with wages, it should have a low tax for equity reasons (Atkinson and Stiglitz (1976)). Which of the two factors dominates depend on the social welfare function and on the shape of the distribution of abilities.

Even though exempting food from sales taxes is a bad idea on efficiency grounds $^{1}$, the majority of the States have a special tax treatment for food.There are many good reasons to think that the food exemptions have a strong impact on the sales tax revenue and rate.

Due and Mikesell (1994), for example, consider that the food exemptions costs a state from $20 \%$ to $25 \%$ of sales and use tax revenue, which means they have to increase the tax rate by $1 \%$ to compensate for the loss of revenue. However, the scarce empirical evidence available does not support the idea of an impact of the food exemption on the yield of the sales tax or the sales tax rate. Merriman and Skidmore (1997) estimate the impact of the food exemption on

\footnotetext{
${ }^{1}$ See for example Iorwerth and Whalley (1998).
} 
the yield of the sales tax (revenue/tax rate) and their results show no significance. Bahl and Hawkins (1997) believe the evidence is consistent with the hypothesis that food exemption lead states to raise the sales tax rate, but their empirical results did not confirm the hypothesis.

One possible explanation for these empirical results is reverse causality, namely, sales tax rates cause a food exemption. I explore this possibility in this paper using data for American states for the period 1977-1998.

\section{Could Higher Sales Tax Rates Cause a Food Exemption?}

One of the main sources of tax revenue for state governments is the sales tax and states face some exogenous shocks that affect negatively the collections. There are several examples of exogenous shocks that have decreased the sales tax revenues. In the case of sales taxes, concrete examples of negative shocks are the effects of internet sales and the increase in household spending on services, which are mainly not taxed. ${ }^{2}$ The impact of some of these shocks might be quite significant, the estimated total state and local revenue loss due to e-commerce, for example, was $\$ 13.3$ billion for 2001 (Bruce and Fox (2001)). Then, if state governments want to keep providing the same level of public goods and services, they must compensate the effects of these shocks increasing the revenue collected either from the sales tax or from other taxes.

\footnotetext{
${ }^{2}$ Between 1970 and 2001, consumption of services rose from $31 \%$ to $44 \%$ of total household purchases.
} 
Additionally, states face some pressure to increase revenue for two reasons.

First, to counterbalance the declines in federal expenditures; and, second, to meet citizens demands for reductions in property taxes subsidized by higher state funding of local expenditures.

For any of these reasons, state goverments may need/want to increase the sales tax rate. However, there are some political costs of raising another dollar of revenues $^{3}$ and, in this particular case, they might be higher because the sales tax is seen as being regressive (the relative size of the consumption budget decreases as income increases). A state government would try to minimize the political costs of raising the sales tax rate and enacting a food exemption might be a way of doing it.

Allowing a food exemption would make the sales tax less regressive. ${ }^{4}$ It is not clear that this would be the case because, among other things, a food exemption favors persons with relatively high preferences for expensive food and poor households already receive food stamps, which are exempted from sales taxes. ${ }^{5}$ Still, the food exemption might be considered a political winner because potentially reduces the regressivity of the sales tax and provides relief to almost every voter. ${ }^{6}$

\footnotetext{
${ }^{3}$ These costs represent the loss in electoral support for the government from levying taxation.

${ }^{4}$ Data from the Consumer Expenditure Survey suggest that households earning less than $\$ 30,000$ (in 2003 dollars) spend basically all of their income while households with incomes above $\$ 200,000$ spend around $37 \%$.

${ }^{5}$ On November 23, 1985, the U.S. senate passed a bill that prohibited states and local governments to impose sales tax on purchases of food made with coupons issued under the food stamp program. The provision has been effective since october 1, 1986 .

${ }^{6}$ Empirically, a food exemption has not been always a political winner. Voters of Idaho, Nevada, and South Dakota rejected an exemption for food in 1984, 1982, and 2004 respectively. Tennessee repealed on June 1 of 1985 legislation that had previously enacted a phasing out
} 
Therefore, a policy instrument like a food exemption may arise as a result of the pursuit of political goals. In fact, many of the complexities of a tax system, including exemptions, can be explained using models that assumed self-interested decision making in both the private and public sectors (Hettich and Winer (1988), Warskett et al (1998)). A support maximizing government would equalize the change in expected political support per dollar of additional revenue across revenue sources. As a result, support-maximizing governments would create tax structures that deviate from the solutions in the optimal tax literature.

A food exemption adds complexity to the sales tax structure, but state governments have incentives to increase the complexity of the tax system because the additional complexity, when properly used, allows the government to minimize the adverse political response of taxpayers to the increased tax burden on them. The analysis of these type of models then, suggests that a broad-based sales tax without special provisions might not be compatible with dynamic political competition in states with hetereogenous individuals.

An increase in the sales tax rate can cause a food exemption because the latter reduces the political cost of the former. A food exemption, for example, might be a political concession of the state government to legislators in exchange for the approval of a sales tax rate increase.

its tax on food. The rate would had decreased from 5.5 to 3.75 in June 1985 and to $2 \%$ in June 1986. After may 1987, food would had been exempted. 


\section{Estimation and Results}

\subsection{Instrumental Variables}

One of the main problems for identifying the effects of the sales tax rate on the existence of food exemptions is that state governments set them both. Empirically, the enactment of a food exemption has been almost always a one time event in each state that has one. The effect of this empirical regularity is that there is much more variation in the tax rates than in the food exemptions, which makes look the sales tax rate as an exogenous variable in the determination of the tax treatment of food. However, there is still a potential endogeneity that has to be considered. State governments do have the possibility of changing the tax treatment of food every period and few of them, like Louisiana and North Carolina, have actually done it.

One possible solution for the endogeneity problem is to use instrumental variables. This solution requires, in this case, to find a variable that is strongly correlated with the sales tax rate and not correlated with unobserved determinants of the food exemption.

The sales tax is a tax that is paid not only by the citizens of the state that uses the tax, but also by citizens from other states or countries who are visiting and consuming in the state. Therefore, the burden of the sales tax is somehow exported and states that received more tourists do so in greater proportion than states with less tourists. ${ }^{7}$ Then, states with higher tourism

\footnotetext{
${ }^{7}$ Pollock (1991), for example, estimates that Connecticut is able to export roughly $22 \%$ of its total sales tax burden.
} 
levels can have higher sales tax rates without increasing the burden of the tax on their own citizens. As a result, I would expect that states in which tourism is an important fraction of the state economy will have higher sales tax rates.

A variable that measures tourism in a state should therefore be highly correlated with the sales tax rate. I use the fraction of state product from hotels and accommodations (SIC code 70) as an instrument for the sales tax rate. ${ }^{8}$ I do believe that this instrument is exogenous with respect to food exemptions. One possible story that would break the exogeneity would be that tourists consume mainly food in the state they visit and if states want to export the burden of the sales tax they should not exempt food from the sales tax. According to this story, it would be less likely that states with higher levels of tourism have a food exemption. However, the food exemptions enacted in all states exempt only food for home consumption and not meals, which are what tourists mainly consume. Therefore, food exemptions benefit mainly the residents of each state. The use of the fraction of GSP that comes from lodging as an instrumental variable for the sales tax then, allows to identify the effects of the sales tax on the probability of having a food exemption. ${ }^{9}$

\footnotetext{
${ }^{8}$ There exist some alternative proxies for the state sales to foreign citizens that I was not able to use. The Travel Industry Association of America, for example, calculates the impact of international visitor spending on state economies, but it is available for only few years. The Census Bureau reports the number of visitors each state receives, but is available only for some states and also for few years.

${ }^{9}$ One potential concern with the use of this instrument is that the fraction of GSP from hotels and lodging can be capturing several things non related at all with the actual number of visitors or the expenditures of foreign citizens in each state. As a way to explore this possibility I ran a regression using the fraction of GSP from lodging as a dependent variable and the other measures described in the previous footnote (international travel expenditures, number of international visitors) for which I have few observations. The results show that the fraction of GSP from hotels is not only strongly and positively correlated with these alternative measures, but it also explains around $45 \%$ of the variation.
} 


\subsection{Data}

I collected data from different sources for the 50 U.S. states during the period 1977-1998. Table (1) presents summary statistics of the data.

The variable sales tax rate is the statutory state sales tax rate. There are five states that do not have sales tax: Alaska, Delaware, Montana, New Hampshire, and Oregon; and there are five states that never changed its sales tax rate over this period: Alabama, Hawaii, Massachusetts, New York, and Pennsylvania.

Table 1: Summary Statistics

\begin{tabular}{llllll}
\hline & Mean & Std. Dev. & Min & Max & $\mathrm{N}$ \\
\hline Sales Tax Rate & 0.047 & 0.011 & 0.02 & 0.08 & 1012 \\
Food Exemption & 0.591 & 0.492 & 0 & 1 & 1012 \\
Unemployment & 0.064 & 0.021 & 0.025 & 0.18 & 1012 \\
Poverty & 0.140 & 0.043 & 0.029 & 0.326 & 1012 \\
Elder 65 & 0.121 & 0.019 & 0.071 & 0.186 & 1012 \\
Income p.c. & 16253 & 6242.05 & 5259 & 37338 & 1012 \\
Population & 5210.31 & 5367.43 & 411.53 & 32987.7 & 1012 \\
Democrat & 0.446 & 0.093 & 0.205 & 0.853 & 1012 \\
Revenue Limit & 0.110 & 0.314 & 0 & 1 & 1012 \\
Expenditure Limit & 0.305 & 0.461 & 0 & 1 & 1012 \\
Food Stamps & 0.084 & 0.034 & 0.016 & 0.23 & 1012 \\
GSP Hotels & 0.011 & 0.020 & 0.0027 & 0.151 & 1012 \\
\hline
\end{tabular}

The variable Food Exemption is a dummy variable equal to 1 if the state exempts (fully or partially) food from sales tax. At the beginning of the sample period (January 1, 1977), there were 19 of the 45 states using sales tax exempting food and by the end of the sample period (December 31, 1998), there were 30. Twelve states enacted a food sales tax exemption during this period: Arizona (July 1,1980), Colorado (January 1, 1980), Georgia $(1996)^{10}$, Illinois

\footnotetext{
${ }^{10}$ The sales tax on food was phased out between October 1, 1996, when the rate was reduced for food from $4 \%$ to $2 \%$, and October 1,1998 , when the rate was zero.
} 
$\left(\right.$ January 1,1980) ${ }^{11}$, Michigan (1978), Missouri $(1997)^{12}$, Nebraska (October 1, 1983), Nevada (July 1,1979), North Carolina $(1997)^{13}$, South Dakota (May 1, 1980 $)^{14}$, Washington (July 1,1978) ${ }^{15}$, and West Virginia $(1979)^{16}$; and two states repealed the food exemption: Louisiana $(1993-97)^{17}$ and West Virginia (1990)

Figure 1 shows the number of states with food exemptions during the period $1977-1998 .^{18}$

The variable Income per capita is the state personal income per capita in dollars, as calculated by the Bureau of Economic Analysis, deflated by the U.S. GDP price deflator. The variable unemployment is the state unemployment rate as percentage of the civilian labor force, estimated by the Bureau of Labor Statistics.

The variables poverty, population and elder 65 are the percentage of persons in the state below the poverty level, the state population in thousands, and the percentage of the population above 65 years old, respectively, all of them as estimated by the U.S. Census Bureau.

\footnotetext{
${ }^{11}$ It reduced the rate on food $1 \%$ in 1980 and then an additonal $1 \%$ on January $1,1981$.

${ }^{12}$ On October 1, 1997, the tax rate on food was reduced from $4.225 \%$ to 1.225 .

${ }^{13}$ Effective January 1, 1997 until June 30, 1998, the state tax rate was reduced to $3 \%$ for purchases of food for home consumption. Then, from July 1, 1998 until April 30, 1999, it was reduced to $2 \%$. Finally, on May 1, 1999, the sales tax on food was repealed.

${ }^{14}$ It increased the sales tax rate $1 \%$ for one year, but kept the tax on food constant.

${ }^{15}$ The exemption was temporarily suspended from May 1, 1982, through June 30, 1983.

${ }^{16}$ It reduced the rate $1 \%$ each year starting in 1979. The food exemption was then repealed in 1990 .

${ }^{17}$ Between 1986 and 1993 the food exemption was partially repealed and food was taxed at lower rates: 1\% between July, 1986, and June, 1989; 3\% between July, 1989 and December 1989; 2\% between January, 1990, and June 1990; and 3\% between July 1990, and June 1993 (the general sales tax rate was $4 \%$ throughout this period). The exemption was then fully repealed during the period July, 1993, and June, 1997. Since July, 1997, and until June, 2000, food was taxed at a lower rate again (3\% while the sales tax rate was $4 \%$ ).

${ }^{18}$ The main source for these data is the Federation of Tax Administrators. However, due to some inconsistencies with other sources I contacted state revenue authorities of Iowa, Louisiana, and Missouri to clarify the contradictions. Douglas A. Shackelford provided the information for North Carolina.
} 
Figure 1: Number of States with a Food Exemption (full or partial)

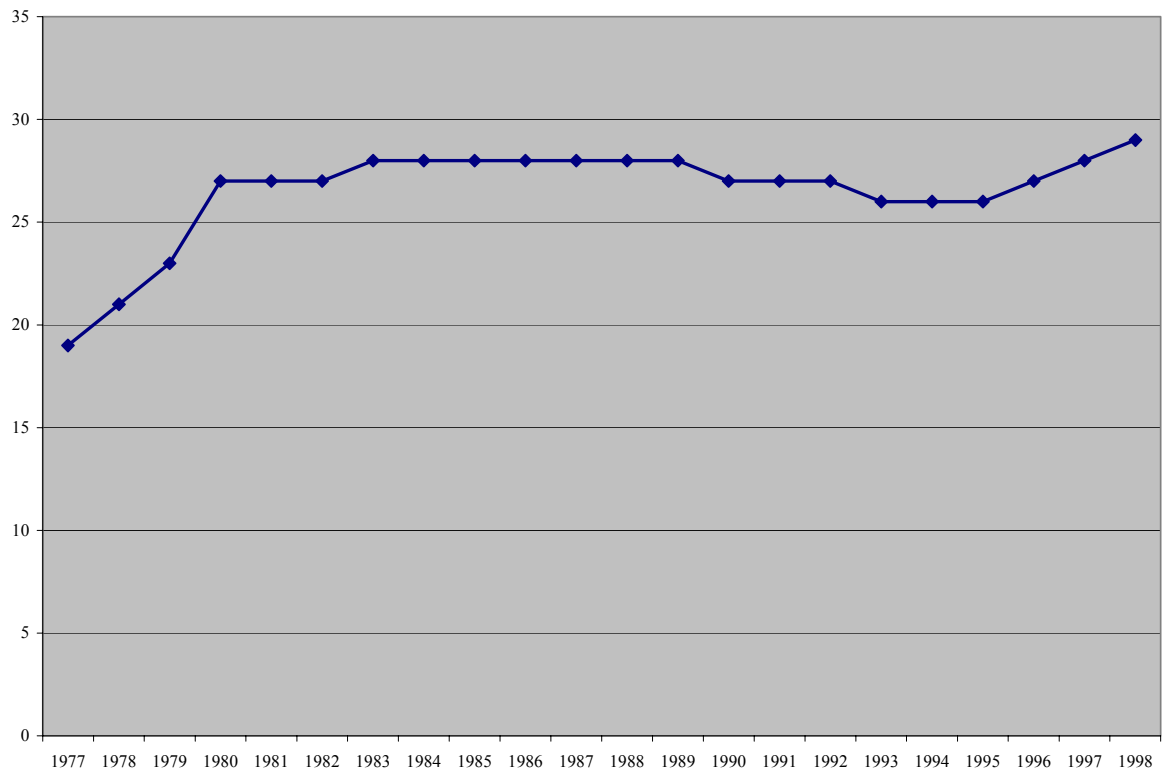

State governments face several statutory constraints when designing their budgets. Several states face expenditures and/or revenue limitations, which constrain the annual growth of them either to a fixed rate or to one based on one or more of the following variables: inflation rate, population growth, growth of personal income, and ratio of revenue to personal income. Using information from the Advisory Commission on Intergovernmental Relations and the Book of the States, I constructed two dummy variables for capturing the effects of these budget limits.

The variables Expenditure Limit and Revenue Limit are a dummy equal to one if the state has a constitutional or statutory provision that constraints the annual growth of expenditures or revenues respectively, and zero otherwise. 
The variable Food Stamps is the fraction of the population using food stamps in each state. It is constructed dividing the number of persons participating in the program, as reported by the Food and Nutrition Service (U.S. Department of Agriculture), by the total population of each state according to the Census Bureau.

\subsection{Results}

Table (2) presents the results of the estimation using pooled data for the period 1980-1998, after dropping from the sample all the states that have no sales tax. The dependent variable is equal to one if the state has a full or partial sales tax exemption for food and zero otherwise. Model (1) shows the Probit estimation just as a comparison to the instrumental variables estimation. The coefficient of the sales tax rate is positive and significant. The marginal effect calculated at the average of the sample is 16.1 , which means that a 1 percentual point increase in the sales tax rate increases the probability of having a food exemption by around 16 percentual points.

Model (2) shows the IV-Probit estimation, where the fraction of the state product from hotels and accommodations is used as an instrumental variable for the sales tax rate. The coefficient of the tax rate is again positive and significant, but much larger in magnitude. The marginal effect calculated at the average of the sample is now 21.2, which implies that a 1 percentual point increase in the sales tax rate increases the probability of having a food exemption by 21 percentual points. As can be seen from the comparison of the Probit estimation 
with the Probit-IV estimation, the endogeneity of the sales tax rate downward biases the estimated coefficient. However, this bias is not large when looking at the marginal effects, the difference between the two is about 5 percentual points.

The coefficient of the poverty rate is negative and significant at $10 \%$. I expected a positive coefficient for this variable, especially if one of the reasons why states have enacted food exemptions is to make the sales tax less regressive. One possible explanation is that poverty rate is not really well measured and it does not vary much from year to year. ${ }^{19}$ To explore this possibility I decided to use the fraction of people using food stamps in each state. Even though this variable is just a proxy for poverty, it is accurately measured because it is the actual count of people receiving food stamps in each state. Model (3) uses food stamp benefits per capita as a measure for poverty instead of using the poverty rate. The coefficient on this variable is also negative, but not significantly different from zero.

Model (4) includes both measures of poverty, the poverty rate and the food stamp benefits per capita, and also adds some statutory and constitutional budget constraints that states face.

The coefficient on the sales tax rate is again positive, significant and about the same magnitude that in the previous two specifications. The marginal effect of the sales tax rate is now 26 percentual points at the means of the sample.

Figure 2 shows the marginal effect of the sales tax rate on the probability on

\footnotetext{
${ }^{19}$ The poverty rate is estimated from annual surveys and then adjusted by the Census data every ten years.
} 
Table 2: Pooled Probit

\begin{tabular}{lllll}
\hline & $(1)$ & $(2)$ & $(3)$ & $(4)$ \\
\hline Sales Tax Rate & 50.40 & 83.56 & 80.64 & 82.17 \\
& $(19.57)$ & $(24.35)$ & $(22.41)$ & $(23.34)$ \\
Poverty & -14.48 & -8.91 & & -7.35 \\
& $(4.802)$ & $(4.84)$ & & $(4.11)$ \\
Income p.c. & 0.0000015 & 0.00027 & 0.00033 & 0.00026 \\
& $(0.00002)$ & $(0.0001)$ & $(0.0001)$ & $(0.0001)$ \\
Population & 0.00012 & 0.00008 & 0.00007 & 0.00008 \\
& $(0.00004)$ & $(0.00005)$ & $(0.00004)$ & $(0.00004)$ \\
Elder 65 & 10.25 & 15.89 & 14.96 & 10.98 \\
& $(9.36)$ & $(9.44)$ & $(9.20)$ & $(9.26)$ \\
Unemployment & 18.77 & 16.56 & 16.45 & 13.79 \\
& $(5.321)$ & $(7.11)$ & $(7.43)$ & $(7.08)$ \\
Food Stamps & & & -7.60 & -4.07 \\
Revenue Limit & & & $(8.23)$ & $(8.45)$ \\
& & & & 0.807 \\
Expenditure Limit & & & & $(0.823)$ \\
Constant & & & & -0.385 \\
Year Dummies & yes & yes & yes & yes \\
Log Likelihood & -424.39 & -401.39 & -407.82 & -387.24 \\
Wald Chi & & 385.24 & 296.48 & 424.5 \\
N & 350.57 & 1012 & 1012 & 1012 \\
\hline
\end{tabular}

having a food exemption for the whole range of sales tax rates. As can be seen from the figure, there is a wide range of marginal effects. A sales tax rate of $2 \%$ increases the probability of a food exemption by around 5 percentual points. The marginal effect increases then up to 32 percentual points for a tax rate of $4.5 \%$, and then decreases dramatically for higher tax rates. For a tax rate of $8 \%$, the highest sales tax rate in the sample, the probability of having a food exemption increases only by 0.5 percentual points.

The coefficient of unemployment is positive and marginally significant at $5 \%$. The marginal effects of unemployment and poverty are 4.5 and -2.4 per- 
Figure 2: Marginal Effects of the Sales Tax Rate

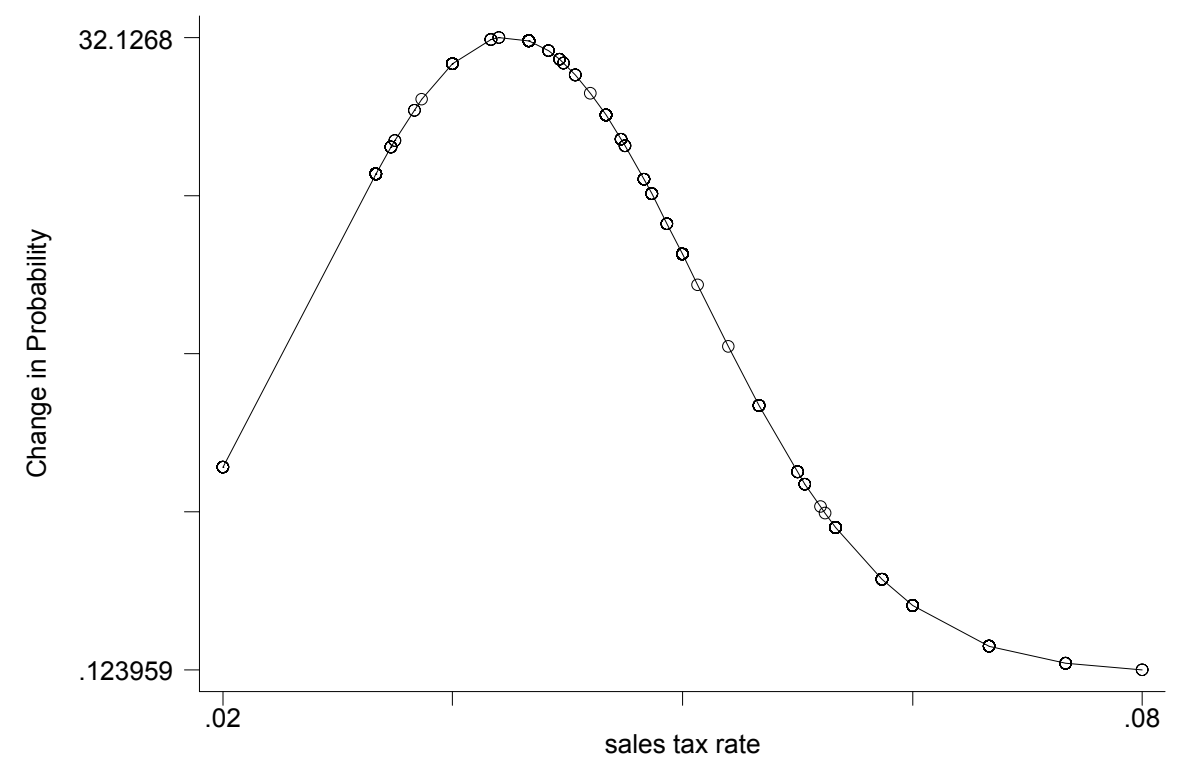

centual points, respectively. Therefore a one percentual point increase in the unemployment and the poverty rates are associated, on average, to a 4.5 and 2.4 percentual points increase and decreased in the probability of having a food exemption, respectively.

The coefficient on the fraction of elder people is positive, but not significant. The marginal effect of the fraction of elder people is 3.5 percentual points. In general, I would expect states with a higher fraction of elder people in the population have lower sales tax rates. The reason for this is that elder people are consuming most of their income (and probably their savings too) and therefore they would prefer low sales taxes (and probably high income taxes because their 
current income is low). ${ }^{20}$ For the same reasons I expected that a state with a higher fraction of elder people would be more likely to have a food exemption, and in that sense the observed positive coefficient is the expected sign even though the non significance is a surprise. It is difficult to know if this is due to the lack of cross-sectional variation on the data or because there is no actual relationship between the food exemption and the fraction of elder people in a state.

The coefficients on population and income per capita are both positive and significant and their marginal effects at the means are 0.0025 and 0.008 percentual points. It is true that these effects are quite small, even though significantly different from zero, but it is interesting that states with higher population levels and/or higher income per capita are more likely to have a food exemption. I did not have a prior for these two variables. It is possible that wealthier states care less about poor people and therefore is less likely that they will have a food exemption. Alternatively, they might care more about poverty and they can also afford a better welfare system, in which case it is also less likely that they will enact a food exemption. A potential explanation for the positive sign observed is that wealthier states want to keep corporate and personal income taxes low, so they finance the provision of public goods using sales tax and, due to political pressure, allow a food exemption in exchange for a higher sales tax rate.

\footnotetext{
${ }^{20}$ There is some anecdotal evidence that supports this claim. In November 9, 1993, for example, Oregon voters turned down a sales tax proposal and senior citizens groups were amongst the groups that strongly opposed the measure.
} 
I also considered the following variables that might affect the tax setting decision of a state government: amount of federal grants per capita, percentage of the state population voting democrat in the closest presidential election, the ratio of state debt to state product, state debt per capita, the fraction of the population that are high school graduates, and a dummy variable equal to one if the state has a statutory or constitutional provision requiring a supermajority voting to increase taxes. However, they were never significant and the results were basically identical if they were included or not, so I decided to drop them from the final specification.

One of the potential problems in the previous analysis is that there is not enough time variation to include state fixed effects. If the omitted state fix effects are correlated with the sales tax rate, the estimated coefficients are biased. The use of instrumental variables eliminates this bias. However, there are others explanatory variables that might be correlated with state fixed effects (poverty for example). As a feasible alternative to control for state fixed effects I differenced the data, using only the first and the ast year of the sample for this purpose.

Table 3 presents the results of the long difference estimation (year 1998 minus year 1977). As can be seen from the table, the estimated coefficient are very similar in sign and magnitude to the previous estimates. However, as it is expected, the standard errors are much larger. Again, just for comparison with the Instrumental Variables estimation, column (1) shows the results of the Probit estimation. The coefficient of the sales tax rate is positive, but significant 
only at $10 \%$. The marginal effect of the sales tax rate on the probability of having a food exemption is 13.64 percentual points at the means of the sample. Model (2) shows the IV-Probit estimation. The coefficient of the sales tax rate is again positive, but now significant at 5\%. Now, the marginal effect of the sales tax rate, at sample means, is 22.7 percentual points.

Table 3: Long Difference Probit

\begin{tabular}{lllll}
\hline & $(1)$ & $(2)$ & $(3)$ & $(4)$ \\
\hline Sales Tax Rate & 54.94 & 88.62 & 84.11 & 87.02 \\
& $(30.21)$ & $(38.64)$ & $(37.56)$ & $(38.14)$ \\
Poverty & 4.244 & 4.74 & & 1.64 \\
& $(2.78)$ & $(2.91)$ & & $(2.81)$ \\
Income p.c. & 0.00005 & 0.00008 & 0.0001 & 0.0001 \\
& $(0.00006)$ & $(0.00007)$ & $(0.00006)$ & $(0.00007)$ \\
Population & 0.00009 & 0.0001 & 0.0001 & 0.0001 \\
& $(0.00008)$ & $(0.00008)$ & $(0.00007)$ & $(0.00007)$ \\
Elder 65 & 41.33 & 34.92 & 36.11 & 30.25 \\
& $(25.76)$ & $(24.99)$ & $(24.60)$ & $(24.02)$ \\
Unemployment & 29.48 & 30.14 & 39.91 & 42.12 \\
& $(20.00)$ & $(21.05)$ & $(24.09)$ & $(21.64)$ \\
Food Stamps & & & 28.36 & 33.18 \\
& & & $(18.54)$ & 18.23 \\
Revenue Limit & & & & 1.08 \\
& & & & $(0.42)$ \\
Expenditure Limit & & & & 0.16 \\
& & & -5.11 & $-5.49)$ \\
Constant & -2.23 & -3.27 & $(1.84)$ & $(2.01)$ \\
& $(1.72)$ & $(1.93)$ & -19.51 & -18.99 \\
Log Likelihood & -20.148 & -20.68 & 10.91 & 11.18 \\
Wald Chi ${ }^{2}$ & 7.96 & 9.42 & 46 & 46 \\
N & 46 & 46 & & \\
\hline
\end{tabular}

The coefficient on Poverty now has a positive sign, which is the one I expected, even though is only significant at the $\%$ confidence level in the first two models and not significant in model (4). The rest of the coefficients are similar in magnitude to the previous ones and they have the same sign, therefore, I 
do not think is relevant to discuss them in detail. However, it is important to mention that, due to the reduction in the degrees of freedom and the consequent increase in the standard errors, some of them are now non significantly different from zero.

\section{Conclusion and Extensions}

In this paper I have explored the impact of the sales tax rate on the probability of having a food exemption. One of the main difficulties in the analysis is that state governments set both the sales tax rate and the exemptions, which causes an endogeneity problem when trying to estimate the effects of one of the tax policy variables on the other one. Using instrumental variables for the tax rate to solve the endogeneity problem, I obtain consistent estimates of the effect of the tax rate on the probability of having a food exemption. The empirical results show a strong positive correlation between the sales tax rate and the existence of a food exemption. A one percentual point increase in the statutory

sales tax rate increases the probability of having a food exemption between 20 and 25 percentual points, on average.

It would be interesting to estimate the effects of the food exemption on the sales tax rate. A suitable instrument for the food exemption is required for that purpose. 


\section{References}

Allers, M., J. De Haan, and C. Sterks (2001), Partisan Influence on the Local Tax Burden in the Netherlands, Public Choice 106.

Atkinson, A.B. and J.E. Stiglitz (1972), The Structure of Indirect Taxation and Economic Efficiency, Journal of Public Economics 1.

Bahl, R. and R. Hawkins (1997), Does a Food Exemption Lead to a Higher State Sales Tax Rate?, Proceedings of the 90th Annual Conference on Taxation, Chicago, Illinois.

Bruce, Donald and William F. Fox (2001), Sales and Local Tax Revenue Losses from E-Commerce: Updated Estimates. Institute for State Studies.

Due, John F. and John I. Mikesell (1994), Sales Taxation: State and Local Structure and Administration, second edition, The Urban Institute Press.

Federation of Tax Administrators, Tax Administrators News, several issues.

Hettich, W. and S.L. Winer (1988), Economic and Political Foundations of Tax Structure, American Economic Review 78(4).

Iorwerth, A. and J. Whalley (1998), Meals on Wheels: Restaurant and Home Meal Production and the Exemption of Food from Sales and Value Added Taxes, NBER Working Paper No. 6653.

Merriman, D. and M. Skidmore (1997), How Have Changes in Demographic and Industrial Structures Influenced Sales Tax Revenues?, Proceedings of the 90th Annual Conference on Taxation, Chicago, Illinois.

Pollock, Stephen K. (1991), Mechanisms for Exporting the State Sales Tax Burden in the Absence of Federal Deductibility, National Tax Journal 44. 
Sandmo, Agnar (1976), Optimal Taxation, Journal of Public Economics 6.

Warskett, G., S.L. Winer, and W. Hettich (1998), The Complexity of Tax Structure in Competitive Political Systems, International Tax and Public Finance 5 . 